Astrid Męczkowska-Christiansen

https://doi.org/10.26881/pwe.2018.43.03

ORCID: 0000-0002-4966-7856

Akademia Marynarki Wojennej

a.meczkowska-christiansen@amw.gdynia.pl

\title{
Uczeń zdolny w perspektywie dyskursu produkcyjnego. W stronę krytycznej rewizji pedagogiki zdolności
}

\section{Summary}

High ability student in a perspective of production discourse. Towards a critical revision of gifted education

Abstract: In this article, I will attempt to outline the "production discourse of giftedness" as currently dominant in the global culture of education and related to its neo-liberal roots. Presented considerations employ the critical perspective of discourse analysis and at the same time are inspired by postFoucaultian approach developed within the field of social sciences, which reveals institutional regimes of practices related to the shaping of expert knowledge, i.a. in the domain of gifted education.

Keywords: high ability student, gifted education, neoliberalism, discourse analysis

Słowa kluczowe: uczeń zdolny, pedagogika zdolności, neoliberalizm, analiza dyskursu

W obszarze międzynarodowej dyskusji obejmującej problematykę ucznia zdolnego coraz częściej stawia się pod znakiem zapytania prawomocność nieproblematyzującego ujęcia jej pojęciowego rdzenia. W literaturze przedmiotu mamy do czynienia z wielością sposobów rozumienia pojęcia „uczeń zdolny”, które w rezultacie przyjmuje postać pustego znaczącego, nasycanego treścią w zależności od interesów reprezentowanych w obszarze definiujących je dyskursów. „Klasyczna” dla tej problematyki antologia Conceptions of Giftedness, autorstwa R.J. Strenberga i J.E. Davidson (2005) prezentuje przynajmniej dwadzieścia różnorakich ujęć problemu wybitnych zdolności, które dostarczają podstaw do konstruowania różnorodnych definicji ucznia zdolnego. Z tego m.in. powodu wstęp do niniejszego artykułu pomija kwestię wprowadzenia określonego sposobu definiowania „ucznia zdolnego", lecz przywołuję w nim - słabiej obecną w rodzimej literaturze pedagogicznej - tezę o społecznym konstruowaniu koncepcji ucznia zdolnego, zawsze osadzanej dyskursywnie, tj. w relacji do określonych sposobów nadawania znaczeń rzeczywistości, powiązanej z formami praktyki społecznej i interesów leżących u ich podstaw.

Podobnie jak w obszarze krytycznie zorientowanych nurtów psychologii rozwojowej czy pedagogiki stawia się tezę o ,wynalezieniu dziecka” (Farson 1992; Kessen 1979), tak w obszarze studiów nad uczniami zdolnymi została wyartykułowana teza o, wynalezieniu uzdolnionych dzieci”. Jak twierdzi jej autor, wynalezienie pedagogiki zdolności przypi- 
suje się splotowi czynników socjokulturowych i politycznych, które w USA, w latach 20. XX w. wykreowały gifted education, odnoszącą się do - rzekomych - problemów edukacji dzieci zdolnych, sygnalizowanych przez edukacyjny establishment (Borland 2005: 3). Jednak kluczowa okoliczność otwierająca dyskurs pedagogiki ucznia zdolnego związana była nie tyle $\mathrm{z}$ interesem dziecka i aranżowaniem form praktyki wspierającej jego rozwój, co z interesem reprezentantów dynamicznie rozwijanego od drugiej dekady $\mathrm{XX}$ wieku psychometrycznego nurtu psychologii rozwojowej, wraz z jej ówcześnie czołowymi przedstawicielami - T.S. Henrym, autorem wpływowej monografii Classroom Problems in the Education of Gifted Children czy L.M. Termanem - postacią uznawaną za „ojca” gifted education w USA a zarazem czołowego dewelopera skali inteligencji Stanforda-Bineta, odpowiedzialnego za powszechność jej wykorzystywania w szkołach amerykańskich. Ta koncepcja, dając początek studiów nad szczególnymi uzdolnieniami dzieci i młodzieży, adresowała je wąsko a zarazem instrumentalnie, poszukując w nich narzędzia wspierającego rozwój i aplikację psychometrycznych narzędzi pomiaru inteligencji ogólnej oraz jej komponentów (Borland 2003: 107).

Współczesna literatura przedmiotu obejmuje liczne próby systematyzacji koncepcji ucznia zdolnego i szczególnych uzdolnień (Davidson 2009: 81-97). Koncepcje te nie są w sensie logicznym - rozłączne, cechując się wielością przenikających się wymiarów. Jednym z nich jest - źródłowe dla wielu - osadzenie analiz nad uczniem zdolnym w dokonaniach psychologii poznawczo-rozwojowej wraz z jej koncepcją podmiotu definiowanego przez pryncypium sprawstwa i poznawczej samodzielności. Ten jednak wymiar bywa współcześnie uzupełniany lub kwestionowany za sprawą zastosowania M. Foucault koncepcji reżimów wiedzy-władzy jako struktur stojących u podstaw wyłaniania się odmiennych typów dyskursów i towarzyszących im praktyk, związanych z pedagogiką zdolności.

Borland, podejmując refleksję nad interesami konstytuującymi praktyki społeczne związane z globalną pedagogia zdolności, nawiązuje do koncepcji Foucaultowskiej, przywołującej J. Benthama ideę panoptycznego nadzoru. Dzięki mechanizmom obserwacyjnym panoptykon funkcjonuje jako laboratorium władzy; służąc do „rozmieszczania jednostek, [tworzenia] hierarchicznej organizacji, wyznaczania centrów i kanałów władzy, określania jej narzędzi i sposobów interwencji” (Foucault 1993: 247). Poprzez testowanie osiągnięć uczniów - twierdzi Borland, przywołując Focaultowskiego ducha - „edukatorzy czynią to samo, przypominając uczniom, że są podporządkowani dorosłym posiadającym przywilej obserwowania ich z pozycji władzy. Co więcej, uczniowie internalizują wiedzę o tym, że są przedmiotami ciągłej obserwacji, tj. testowania (Borland 2005: 5) i w konsekwencji postępują tak, jak gdyby stali się strażnikami we własnym więzieniu. $\mathrm{Z}$ tego punktu widzenia powszechne oddziaływanie narzędzi psychometrycznych pełniło funkcję nadzoru, a także normalizującej sankcji, redukującej ludzką różnorodność do jednowymiarowego continnum rozpiętego pomiędzy biegunami: zdolny vs. „ograniczony” (tamże, s. 6), sama zaś pedagogika zdolności stała się zasłoną skutecznie mistyfikującą interes społecznej segregacji, hierarchizacji i normalizacji, stanowiących sposoby sprawowania władzy w społeczeństwie karceralnym (Foucault 1993). Borland nakreślił w ten 
sposób podstawowe okoliczności stojące u podstaw wyłonienia się ,produkcyjnego dyskursu ucznia zdolnego" (określenie moje) jako jednej z odmian pedagogii zdolności.

Kluczowe dla mojego przedsięwzięcia pojęcie dyskursu - choć wywiedzione z tradycji postfoucaultowskich studiów społecznych (zob. Fairclough 2003) - odnoszę do koncepcji dyskursu jako struktury integrującej poziomy „teorii” (tj. systemu wypowiedzi językowych generujących naukę jako „dyskursywną jedność”, Foucault 2009: 324) i praktyki społecznej, spiętych wielopoziomowymi relacjami władzy-wiedzy. W tym sensie praktyki dyskursywne posiadają moc formującą własne obiekty (Foucault 1977: 2009) a jednocześnie „obiektywizujące podmiotowości", tj. ujmujące je w urzeczowionych kategoriach przedmiotów wiedzy eksperckiej - jak ma to miejsce w wypadku kategorii „ucznia zdolnego”.

\section{Produkcyjny dyskurs ucznia zdolnego}

Uprzednio przywołane analizy Borlanda zasygnalizowały obecność interesów merytokratycznych towarzyszących społecznemu konstruowaniu pedagogiki zdolności. Jak twierdzi D.Y. Dai (2009: 71), dyskurs ucznia zdolnego zrodził się za sprawą darwinistów, takich jak Goddard, a wcześniej Galton, służąc kreowaniu „platońskiej elity” wyspecjalizowanych psychologów. Przywołując perspektywę foucaultowską, dostrzeżemy tu także interes polityczny, odnoszący się do sprawowania dyscyplinarnych form władzy nad społeczeństwem, dla których jednym z podstawowych narzędzi jest normalizacja - dostarczająca społecznej spójności przez przekreślenie różnic, decydująca o sprawnej alokacji jednostek w systemie rang i szeregów, konstruująca jednostki sprawne, poddane, zdyscyplinowane i przywiązane do rytualnych form funkcjonowania hierarchicznie zorganizowanych systemów społecznych. Niemniej podobne zarzuty trudno byłoby odnieść do całego nurtu psychologii poznawczo-rozwojowej czy psychologii różnic indywidualnych, stanowiących intelektualne zaplecze dla badań nad inteligencją i uzdolnieniami. Chodzi tu raczej o krytykę zaangażowania i opowiedzenia się po stronie selektywnej funkcji pedagogiki uzdolnień; chodzi o autorytet legalizujący jej proselektywne i normalizujące działania.

Dla teoretyków i badaczy osadzonych w obszarze produkcyjnego dyskursu ucznia zdolnego charakterystyczne jest przekonanie, po pierwsze - o „empirycznej obecności” fenomenu ucznia zdolnego, po drugie - o wyjątkowej generatywności obdarzonych nimi podmiotów. Dominujące spojrzenie na koncepcję ucznia zdolnego odnosi ją do zjawiska istniejącego obiektywnie, budując uzasadnienia w tej kwestii w oparciu o wyniki psychometrycznych pomiarów wskazujących na indywidualne różnice pomiędzy ludźmi'. Jednak de-

\footnotetext{
1 Rodzima literatura przedmiotu kładzie nacisk na psychologizowane ujęcie ucznia zdolnego, lokując specyfikę tego zjawiska w immanentnych charakterystykach podmiotu i identyfikując całą gamę szczegółowych charakterystyk uczniów zdolnych (zob. Bieluga 2003). Podejście to pozostaje w związku z odnoszeniem analiz nad uczniem zdolnym do psychologicznej problematyki inteligencji. Wraz z rozwojem i różnicowaniem się tej ostatniej (np. w postaci wyłonienia się teorii inteligencji wielorakich) studia nad uczniem zdolnym wskazują na coraz liczniejsze pola jego szczególnych uzdolnień - przykładem jest tu model struktur zdolności kierunkowych zaproponowany przez W. Limont (2008).
} 
finiowanie szczególnych zdolności jest sprawą przyjęcia określonych wartości, a nie empirycznego wglądu (Borland 2003: 112). Z kolei generatywność ucznia zdolnego została przez Granta i Piechowskiego (1999: 8) porównana do spojrzenia farmerów na hodowane przez nich krowy i świnie: farmerzy zawsze postrzegają trzodę pod kątem jej produktywności i zasobów, jakie wniosą w gospodarstwo - twierdzą autorzy. Podobnie postrzega się wybitnie uzdolnionych - ich zasoby mają generować przyszłe osiągnięcia; chodzi tu jednak jedynie o te osiągnięcia, które są społecznie uznawane i cenione, a zatem niekoniecznie wynikają z ,wewnętrznych” potrzeb podmiotu. To, czego doświadczają wyjątkowo uzdolnieni, co myślą i czują, pozostaje przedmiotem poznawczej i aksjologicznej ignorancji (por. tamże).

Rzecz jasna, nie wszystkie podejścia do problematyki wybitnych zdolności obejmują taki właśnie punkt widzenia. Swoisty kontrapunkt stanowią w tym wypadku poglądy akcentujące potrzeby samorealizacyjne uczniów zdolnych, a także specyficzne zagrożenia rozwojowe. Humanistyczne podejście w obszarze psychologii czy pedagogii zdolności kieruje uwagę $\mathrm{ku}$ - ignorowanym z perspektywy produkcyjnego dyskursu ucznia zdolnego - kwestiom jego emocjonalności, świadomości, szczególnej wrażliwości (Roeper 1982: 21). Zwraca się uwagę na fakt, że wybitne zdolności są przejawem asynchronii rozwojowej, dotykającej rozwoju jako „całości” (Silverman 1997 i in.). Analizy te idą w kierunku uznania odmiennej struktury osobowości (Self) podmiotów szczególnie uzdolnionych ${ }^{2}$. Nie jest tak - twierdzi Roeper - że wyjątkowe zdolności stanowią jakiś „dodatek” do typowo funkcjonującej struktury ,,ja”, lecz całościowo ją przekształcają, wywołując, z racji szczególnego sposobu doświadczania świata, potencjalne konflikty z oczekiwaniami otoczenia. Ta odmienność - z perspektywy PDUZ - jest jednak postrzegana jako pewien „defekt” tkwiący w samym dziecku (Roeper 1996: 18), zaś jego potrzeby są definiowane apriorycznie, ,z zewnątrz”, stosownie do treści eksperckiej wiedzy na temat „ucznia zdolnego", a następnie narzucane mu w postaci społecznych oczekiwań. Co więcej, praktyki te utożsamia się z kwestią specjalistycznego wspierania osiągnięć ucznia.

Z perspektywy PDUZ znaczenia obecne w pojęciu giftedness generują praktyki określane mianem „rozwoju talentów”, zorientowane na wzmacnianie społecznie użytecznej produktywności jednostek wybitnych. O ile przyjąć foucaultowską perspektywę analizy dyskursu jako poszukiwania ukrytych form relacji pomiędzy władzą a rzeczywistością społeczną, w tym edukacyjną, to tę drugą zawsze będziemy postrzegać w odniesieniu do jej nieuchronnie politycznego wymiaru. Stąd rodzi się pytanie o to, jak rozumieć potencjalną produktywność ucznia zdolnego w kontekście relacji pomiędzy edukacją a polityką/ekonomią3. Patrząc na rzecz z perspektywy globalnych przeobrażeń społeczno-ekonomicznych ostatnich dziesięcioleci, dostrzega się związki pomiędzy rosnącym uznaniem społecznym dla pedagogiki zdolności a polityką w jej wymiarach społecznym i ekonomicznym - aktualnie

\footnotetext{
2 Mamy tu zatem do czynienia z przypadkiem opozycyjnego - w stosunku do PDUZ - dyskursu ucznia zdolnego.

3 Stawiając ukośnik, podkreślam uspójnioną domenę polityki i ekonomii, zgodnie z wynikami analiz relacji edukacja - polityka - ekonomia w odniesieniu do rzeczywistości neoliberalnej (Potulicka, Rutkowiak $2010 \mathrm{i}$ in.).
} 
kwestia ta wydaje się dotyczyć niemal całego świata, tj. państw takich jak USA, kraje Unii Europejskiej, Federacja Rosyjska, wybrane kraje arabskie i azjatyckie (Katar, Kuwejt, Singapur, Korea Południowa, Chiny i in.). Uznanie to nakłada się na rozwój ekonomii i polityki uprawianej w neoliberalnej perspektywie przedkładającej ,zysk ponad ludzi” (Chomsky). Przykładowo, w kontekście reformy oświatowej w USA, przeprowadzanej w latach 80. XX wieku, uczeń zdolny był przedstawiany w kategoriach zasobów ludzkich jako kapitału, którego rozwój przełoży się na wzrost gospodarczy. Poprzedzający wspomnianą reformę raport o stanie edukacji A Nation at Risk (1983) obejmował szczególne zalecenia dotyczące edukacji dzieci zdolnych, co przyniosło wprowadzenie nowego ustawodawstwa w tym zakresie (Ustawa Jacoba Javitsa 1988). Współczesnym przykładem podejmowania niezwykle dynamicznych działań na rzecz uczniów zdolnych jako ,paliwa” dla gospodarczego wzrostu są ,,azjatyckie tygrysy”, w tym Singapur, gdzie edukacja uczniów zdolnych stała się priorytetem państwowym i jest realizowana poprzez selekcję „talentów”, a następnie kształcenie ich w ramach specjalnych programów edukacyjnych realizowanych przez wybrane szkoły (Gifted Education Programme 2017).

Produkcyjny dyskurs ucznia zdolnego ma zatem charakter globalny. Idee edukacyjne w tym obszarze były propagowane przez ponadnarodowe organizacje takie jak UNESCO (1998), OECD (2006), World Council for Gifted and Talented Children (WCGTC) czy The International Centre for Innovation in Education (ICIE), czyniąc to w intencji rozwoju zasobów ludzkich i konkurencyjności gospodarek krajowych. Gifted education w wielu regionach świata stała się odpowiedzią na kryzysy ekonomiczne (przykład stanowią kraje azjatyckie w odpowiedzi na tzw. kryzys walutowy z roku 1997) lub przeświadczenie o niedostatecznej eksploatacji zasobów ludzkich na rzecz gospodarczego wzrostu (np. Indie i kraje arabskie). Aktualnie państwa takie jak Chiny, Korea, Japonia czy Singapur, uruchamiając edukacyjne strategie rozwoju zasobów ludzkich, czynią to w intencji rozwoju innowacyjnego i kreatywnego rozwoju gospodarek (zob: Ibata-Arens 2012); podobną politykę realizują państwa Środkowego Wschodu (David 2012). Wiele z krajów wybrało specjalistyczną ścieżkę wspierania uzdolnień z przedmiotów ścisłych z naciskiem na kreowanie technokratycznych elit (np. Chiny), inne wspierają różnorodność uzdolnień (np. Singapur, gdzie jeden z kluczowych - identyfikowanych i wspieranych obszarów dotyczy kreatywności literackiej).

Aktualne europejskie, a także krajowe regulacje w zakresie wspierania uczniów zdolnych wyrastają na tle Strategii Lizbońskiej (2000), obejmującej deklaracje działań na rzecz wzmocnienia potencjału gospodarczego Unii Europejskiej. Na tym tle rozwinął się dyskurs szczególnego potencjału generatywnego ucznia zdolnego, wielokrotnie ujmowanego w kategoriach „kreatywnych zasobów” o szczególnym znaczeniu dla rozwoju gospodarki UE i rynków krajowych. Na forum ekspertów w Nijmegen (2002) sformułowano postulat, aby edukację uczniów zdolnych uznać za priorytet w oświatowych działaniach UE (Limont 2004), w roku 2006 Eurydice opublikowało ważny raport promujący zagadnienia identyfikacji wybitnych zdolności uczniów (Eurydice 2006), zaś w roku 2013 wydano rekomendację unijną dotyczącą szczególnego wsparcia dla uczniów zdolnych, osadzoną w kontekście priorytetów rozwoju gospodarczego i przezwyciężania ekono- 
micznego kryzysu poprzez wspieranie gospodarki opartej na wiedzy EU (EESC 2013). Najwyższym rangą krajowym dokumentem wpisującym się w ekonomiczną perspektywę wyłaniania i wspierania rozwoju ucznia zdolnego jest prognoza przygotowana przez Radę Ministrów Polska 2030 (Boni 2009), w której podkreślono elitarną funkcję edukacji uczniów zdolnych, której istotą jest „wyławianie talentów już we wczesnej fazie” (tamże, s. 9). Dostarczając podstawy dla wspomnianej prognozy, Raport o kapitale intelektualnym Polski (2008) kładł nacisk na systematyczne monitorowanie osiągnięć uczniów, zgodnie z przekonaniem, iż „[t]alenty w polskich szkołach nie będą się rozwijać, o ile nie zostaną wprowadzone systemowe rozwiązania, które pozwolą szkołom regularnie i w jednolity sposób monitorować osiągnięcia każdego ucznia" (tamże, s. 62).

Programowe działania na rzecz uczniów zdolnych były zawarte w deklaracjach Ministerstwa Edukacji Narodowej i Sportu, które w Strategii rozwoju edukacji na lata 20072013 sformułowało zadania polegające na udzielaniu pomocy uczniom zdolnym w postaci kół zainteresowań i opieki naukowej. Wdrażaniu tejże strategii towarzyszyło uruchomienie środków finansowych UE w ramach programu operacyjnego Kapitał Ludzki (20072013), spójnego z wytycznymi Strategii Lizbońskiej. Przyniosło to zainteresowanie wielu podmiotów III sektora działaniami na rzecz uczniów zdolnych, co mogło mieć także podłoże komercyjne. Najszerszym spośród tychże działań był projekt pt. Opracowanie $i$ wdrażanie kompleksowego systemu pracy z uczniem zdolnym (realizowany przez powołany przez MEN Ośrodek Rozwoju Edukacji w latach 2010-2014)4. Realizacja projektu miała charakter ogólnokrajowy, obejmując działania polegające przede wszystkim na identyfikacji uczniów zdolnych, rozwijaniu oferty zajęć pozalekcyjnych, organizowaniu konkursów i olimpiad przedmiotowych.

Nacisk na psychometryczną identyfikację uczniów zdolnych niezmiennie stanowi jedną z charakterystycznych praktyk osadzonych w PDUZ, czemu dają wyraz zarówno zagraniczne jak i krajowe rekomendacje. Funkcją tych praktyk - w sensie oficjalnym - winno być wspieranie rozwoju talentów, nierzadko przyjmujące instrumentalną metaforę „,szlifowania brylantów". Globalne praktyki alokowania zidentyfikowanych uczniów w różnych typach klas i szkół bądź udzielania im indywidualnego wsparcia są bardzo zróżnicowane, niemniej są one zawsze podporządkowane kreowaniu nowych elit merytokratycznego społeczeństwa (por. Margolin 1996) na drodze „wyławiania talentów”, ich subsydiowania (za pośrednictwem systemów grantów publicznych bądź prywatnych) oraz kierowania na ekskluzywne tory kształcenia. Funkcja identyfikacji i alokacji uczniów o szczególnych zdolnościach spotyka się z krytyką ze strony podejść bardziej egalitarystycznych, gdzie w krajach takich jak Norwegia czy Finlandia promuje się ich integracyjne kształcenie w ramach zróżnicowanej grupy, rezygnując w ogóle z określenia „uczeń zdolny”. Identyfikacja ta jest także krytykowana ze względu na możliwość etykietyzacji i odrzucenia uczniów zdolnych przez grupę rówieśniczą (np. poprzez tworzenie formalnych wykazów

\footnotetext{
$4 \mathrm{Na}$ intensywność prac w tym zakresie miała wpływ m. in. negatywna ocena przez NIK działań MEN w zakresie realizacji zadań wynikających z Ustawy o systemie oświaty, a dotyczących identyfikacji i wsparcia ucznia zdolnego w szkole (oceny dokonano w roku 2007).
} 
uczniów zdolnych w praktyce szkoły brytyjskiej), a także ze względów psychologicznych, łączonych m.in. ze szczególnym obciążeniem oczekiwaniami otoczenia. Ponadto selekcja i identyfikacja uczniów zdolnych może pełnić funkcję stygmatyzującą zarówno wobec nich samych, jak i tych, którzy pod ową kategorię nie podpadają. Może działać osłabiająco na integrację rówieśników, rozbijając wewnątrzgrupowe więzi i społeczną jedność szkoły (Dal 2009: 70; Borland 2003).

Oficjalna wersja PDUZ przemilcza sprawę znaczenia kapitału społecznego dla identyfikacji i wspierania ucznia zdolnego, w pewnym sensie wpisując się w neoliberalną mitologię awansu „od pucybuta do milionera”, zakładającą ontologię równości szans. Jednak już w samych mechanizmach identyfikacji uczniów zdolnych odnaleźć można i te kryteria, które są związane z dziedziczeniem kapitału społecznego. Należą do nich m.in. rozbudowany kod językowy, zainteresowania czytelnicze, preferencje dotyczące komunikacji z osobami dorosłymi, wysokie aspiracje edukacyjne (Silverman 1999; Bieluga 2003: 21), które stanowią tradycyjnie już uznane efekty socjalizacji w domenie habitusu klasy średniej. Analizy dokonywane na świecie wykazują także nadreprezentację uczniów o wysokim kapitale społecznym w edukacyjnych obszarach dedykowanych kształceniu uczniów zdolnych (Dal 2009: 70; Sapon-Shevin 2003: 132 i nn.; Goings, Ford 2018). Ma to związek z faktem, iż znaczącym czynnikiem wspierającym osiągnięcia ucznia zdolnego jest socjalizacyjne oddziaływanie rodziny i jej współpraca ze szkołą oraz nabywanie rozbudowanego kodu językowego (Reichenberg, Landau 2009), co wyraźnie łączy się z etosem klasy średniej.

\section{Produkcyjny dyskurs ucznia zdolnego: perspektywa szkoly ${ }^{5}$}

Zestawiając ze sobą poziom oficjalnych deklaracji dotyczących celowości i praktyk wspierania ucznia zdolnego w polskiej szkole z polem praktyki edukacyjnej, dostrzega się pewną problematyczność statusu ucznia zdolnego jako wymagającego specyficznego podejścia, niekiedy „kłopotliwego” i niepasującego do świata szkoły. Szkoła podejmuje wysiłki idące w kierunku ,technicznego zagospodarowania” oraz instrumentalnego wykorzystania jego potencjału, choć nie zawsze ma to dodatnie znaczenie dla rozwoju ucznia czy też oficjalnie deklarowanego priorytetu ,inwestycji w kapitał ludzki”. Szkoła wydaje się w tym zakresie pozostawać w zawężonej czasoprzestrzeni „tu i teraz”, odnoszącej się do problemów bieżących, które w wypadku pracy z uczniem zdolnym można sprowadzić do następującego pytania: Jak ,zagospodarować” ucznia zdolnego z pożytkiem dla szkoły a zarazem uniknąć potencjalnych problemów, które może generować jego obecność w ramach rytualnej przestrzeni i regularnego rytmu pracy tej instytucji? Szkoła dokonuje także eksploatacji ucznia zdolnego w celu wykazywania „na zewnątrz” jego wybitnych osiągnięć, co przekłada się na ekspozycję wysokiej jakości pracy szkoły i dowodzi jej prestiżu. Tym, co jednak wydaje się najbardziej charakterystyczne dla rodzimej edukacji,

\footnotetext{
5 Ta część tekstu obejmuje wybrane konkluzje z niepublikowanych analiz nad szkolną perspektywą postrzegania ucznia zdolnego i towarzyszących jej praktyk, które zamierzam przedstawić w kolejnej publikacji z tego cyklu.
} 
jest kulturowy opór szkoły wobec stosowania aktywnych strategii uczenia się, które są ekspediowane poza obszar uczenia się „codziennego”, pomimo wyników licznych badań wskazujących na ich podstawowe znaczenie nie tylko da rozwoju tych szczególnie uzdolnionych, lecz każdego ucznia (Klus-Stańska 2000; Tomlinson 1996).

Z punktu widzenia krytycznej analizy dyskursu interesującym pytaniem jest to, jak dyskurs powołuje swój podmiot do istnienia i w jaki sposób go dyscyplinuje do warunków społecznych naznaczonych dominacją, hierarchizacją i rywalizacją. W obszarze produkcyjnego dyskursu ucznia zdolnego dokonuje się swoistej atomizacji jego przedmiotu, zgodnie z neoliberalnym założeniem, że jednostka jest jedynym rzeczywistym bytem. Potencjału ucznia zdolnego nie tylko nie postrzega się jako osadzonego w relacjach łączących go ze środowiskiem społecznym i kulturowym, stanowiących naturalny kontekst rozwoju, lecz w ramach tego dyskursu „wytwarza się go” (pojęcie M. Foucault) jako wyizolowaną monadę, naznaczoną takimi charakterystykami jak nastawienie na rywalizację, sprawność, szybkość (uczenia się, działania), produktywność (generowania osiągnięć) i podatność (rozumiana w kategoriach motywacji do „poznawania” tego, co oferuje bądź czego oczekuje szkoła, zaś w przyszłości - otoczenie społeczne). Innymi słowy, dokonuje się tu redefiniowania ludzkiej natury.

\section{Literatura}

Bieluga K. (2003), Nauczycielskie rozpoznawanie cech inteligencji i myślenia twórczego. Kraków, Oficyna Wydawnicza Impuls.

Boni M. (red.) (2009), Polska 2030. Wyzwania rozwojowe. Warszawa, Kancelaria Prezesa Rady Ministrów.

Borland J.H. (2003), The death of giftedness. Gifted education without gifted children. In: J.H. Borland (ed.), Rethinking Gifted Education. New York-London, Teachers College Press.

Borland J.H. (2005), Gifted education without gifted children. The case for no conception of Giftedness. In: R.J. Sternberg, J.E. Davidson (eds.), Conceptions of Giftedness. New York, Cambridge University Press.

Council of Europe (1994), Education for Gifted Children. Parliamentary Assembly Recommendation 1248. http://assembly.coe.int/nw/xml/XRef/Xref-XML2HTML-EN.asp?fileid=15282\&lan$\mathrm{g}=\mathrm{en}(20.09 .2018)$.

Dai, D.Y. (2009), Essential Tensions Surrounding the Concept of Giftedness. In: L. V. Shavinina (ed.), International Handbook on Giftedness. Dordrecht, Springer.

David H. (2012), Gifted Education in Middle East. In: E. Shaunessy-Dedrick, M. Foley Nicpon (eds.), APA Handbook of Giftedness and Talent. Washington D.C., APA Books.

Davidson J.E. (2009), Contemporary Models of Giftedness. In: L.V. Shavinina (ed.), International Handbook on Giftedness. Dordrecht, Springer.

EESC (2013), Opinion of the European Economic and Social Committee on "Unleashing the potential of children and young people with high intellectual abilities in the European Union" 2013/C 76/01, Official Journal of European Union, https://eur-lex.europa.eu/legal-content/EN/TXT/?ur $\mathrm{i}=$ uriserv:OJ.C_.2013.076.01.0001.01.ENG (21.08.2018).

Eurydice (2006), Specific Educational Measures to Promote all Forms of Giftedness at School in Europe Working Document. http://www.indire.it/lucabas/lkmw_file/eurydice/Specific_measures_giftedness_EN.pdf (21.08.2018). 
Fairclough N. (2003), Analyzing discourse: Textual analysis for social research. London, Routledge. Farson R. (1992), O wynalezieniu dzieci. W: K. Blusz (red.), Edukacja i wyzwolenie. Kraków, Oficyna Wydawnicza Impuls.

Foucault M. (1977), Archeologia wiedzy. Warszawa, PIW.

Foucault M. (1993), Nadzorować i karać. Narodziny więzienia. Warszawa, Aletheia.

Foucault M. (2009), O archeologii nauk. W odpowiedzi Kotu epistemologicznemu. W: L. Rasiński (red.), Język, dyskurs, spoteczeństwo. Warszawa, PWN.

Gallagher, J., Harradine, C., Coleman, M. (1997), Challenge or boredom: Gifted students' view on their schooling. "Roeper Review", 3 (19).

Goings, R.B., Ford, D.Y. (2018), Investigating the intersection of poverty and race in gifted education journals: 15-year analysis. "Gifted Child Quarterly", 1 (62).

Grant B.A., Piechowski M.M. (2009), Theories and the Good: Toward Child-Centered Gifted Education. "Gifted Child Quarterly", 4 (43).

Ibata-Arens K. (2012), Race to the Future: Innovations in gifted and enrichment education in Asia, and implications for the United States. "Administrative Sciences", 1 (2).

Kessen W. (1979), The American child and other cultural inventions. "American Psychologist", 10 (34).

Klus-Stańska D. (2000), Konstruowanie wiedzy w szkole. Olsztyn, Wydawnictwo UWM.

Limont, W. (2004), Wprowadzenie. W: W. Limont (red.), Teoria i praktyka edukacji uczniów zdolnych. Kraków, Oficyna Wydawnicza Impuls.

Limont W. (2008), Model struktur zdolności kierunkowych i jego implikacje teoretyczne i praktyczne. W: W. Limont, J. Cieślikowska, J. Dreszer (red.), Zdolności. Talent. Twórczość. T.I. Toruń, Wydawnictwo UMK.

Margolin L. (1996), A pedagogy of privilege. "Journal for the Education of the Gifted", 1 (19).

OECD (2006), Personalizing Education. http://www.oecd.org/education/school/personalisingeducation.htm (12.05.2018).

Potulicka E., Rutkowiak J. (2010), Neoliberalne uwikłania edukacji, Kraków, Oficyna Wydawnicza Impuls.

Raport o kapitale intelektualnym Polski. Zespół Doradców Strategicznych Prezesa Rady Ministrów, Warszawa 2008.

Reichenberg A., Landau E. (2009), Families of Gifted Children. In: L.V. Shavinina (eds.), International Handbook on Giftedness. Dordrecht, Springer.

Roeper, A. (1982), How the gifted cope with their emotions. "Roeper Review", 2 (5).

Sapon-Shevin M. (2003), Equity, Excellence, and School Reform. Why Is Finding Common Ground So Hard? In: J.H. Borland (ed.), Rethinking gifted education. New York, Teachers College Press.

Silverman L.K. (1999). Characteristics of gifted children. In: P.M.H. Atwater, Children of the new millennium. New York, Three Rivers Press.

Silverman L.K. (1997), The construct of asynchronous development. "Peabody Journal of Education", 3-4 (72).

Strenberg R.J., Davidson J.E. (eds.) (2005), Conceptions of Giftedness. New York, Cambridge University Press.

Tomlinson, C. (1996), Good teaching for one and all. Does gifted education have an instructional identity? "Journal for the Education of the Gifted", 2 (20).

UNESCO (1998), Educating students with high ability. http://unesdoc.unesco.org/images/0013/ 001383/138328e.pdf, 5.09.2018. 